University of Nebraska - Lincoln

DigitalCommons@University of Nebraska - Lincoln

2005

\title{
Habitat and nesting of Le Conte's Sparrows in the northern tallgrass prairie
}

\author{
Maiken Winter \\ State University of New York \\ Jill A. Shaffer \\ USGS Northern Prvirie Wildlife Research Center, jshaffer@usgs.gov \\ Douglas $\mathrm{H}$. Johnson \\ USGS Northern Prairie Wildlife Research Center, Douglas_H_Johnson@usgs.gov \\ Therese M. Donovan \\ University of Vermont, therese.donovan@uvm.edu \\ W. Daniel Svedarsky \\ University of Minnesota \\ See next page for additional authors
}

Follow this and additional works at: https://digitalcommons.unl.edu/usgsnpwrc

Part of the Other International and Area Studies Commons

Winter, Maiken; Shaffer, Jill A.; Johnson, Douglas H.; Donovan, Therese M.; Svedarsky, W. Daniel; Jones, Peter W.; and Euliss, Betty R., "Habitat and nesting of Le Conte's Sparrows in the northern tallgrass prairie" (2005). USGS Northern Prairie Wildlife Research Center. 204.

https://digitalcommons.unl.edu/usgsnpwrc/204

This Article is brought to you for free and open access by the US Geological Survey at DigitalCommons@University of Nebraska - Lincoln. It has been accepted for inclusion in USGS Northern Prairie Wildlife Research Center by an authorized administrator of DigitalCommons@University of Nebraska - Lincoln. 


\section{Authors}

Maiken Winter, Jill A. Shaffer, Douglas H. Johnson, Therese M. Donovan, W. Daniel Svedarsky, Peter W. Jones, and Betty R. Euliss 


\title{
Habitat and nesting of Le Conte's Sparrows in the northern tallgrass prairie
}

\author{
Maiken Winter, ${ }^{1,6}$ Jill A. Shaffer, ${ }^{2}$ Douglas H. Johnson, ${ }^{2}$ Therese M. Donovan, ${ }^{3}$ \\ W. Daniel Svedarsky, ${ }^{4}$ Peter W. Jones, ${ }^{5}$ and Betty R. Euliss ${ }^{2}$ \\ ${ }^{1}$ State University of New York, College of Environmental Sciences and Forestry, Syracuse, New York 13210 USA \\ ${ }^{2}$ U.S. Geological Survey, Northern Prairie Wildlife Research Center, Jamestown, North Dakota 58401 USA \\ ${ }^{3}$ U.S. Geological Survey, Vermont Cooperative Fish and Wildlife Research Unit, University of Vermont, \\ Burlington, Vermont 05405 USA \\ ${ }^{4}$ Northwest Research and Outreach Center, University of Minnesota, Crookston, Minnesota 56716 USA \\ ${ }^{5}$ Natural Resources Committee, South Burlington, Vermont 05403 USA
}

Received 5 April 2004; accepted 24 May 2004

\begin{abstract}
Little is known about the breeding biology of the Le Conte's Sparrow (Ammodramus lecontei $i$ ), probably because of its secretive nature. We provide new information on several aspects of Le Conte's Sparrow breeding biology, including rates of nest parasitism by Brown-headed Cowbirds (Molothrus ater) and potential factors affecting breeding densities and nesting success of the species. Our study was conducted in the tallgrass prairie of northwestern Minnesota and southeastern North Dakota during 1998-2002. Breeding densities varied among years, but this variation was not clearly linked to climatic patterns. Vegetation had some influence on densities of Le Conte's Sparrows; densities were highest in grasslands with moderate amounts of bare ground. Prairie patch size and the percentage of shrubs and trees in the landscape had no recognizable influence on density. Nesting success was highly variable among sites and years and increased slightly with distance from trees. Rates of nest parasitism were low (1 of 50 nests parasitized), and clutch sizes were similar to those of other studies of Le Conte's Sparrows.
\end{abstract}

SINOPSIS. Habitat y anidamiento de Ammodramus leconteii en las praderas de yerbas altas del norte

Se concoce poco sobre el anidamiento del pinzón Ammodramus leconteii, probablemente por su naturaleza secretiva. Proveemos información de varios aspectos de la biología reproductiva, incluyendo la tasa de parasitismo de parte de Molothrus ater, y los factores potenciales que afectan la densidad reproductiva y el éxito de anidamiento de la especie. El estudio se llevó a cabo de 1998-2002, en las praderas de yerbas altas del noroeste de Minesota y el sureste de Dakota del Norte. La densidad reproductiva varió entre los diferentes años de estudio, aunque la variación no estuvo vinculada a patrones climáticos. La vegetación influyó en la densidad del ave: se encontraron las mayores densidades en yerbasales con áreas moderadas de suelo desnudo. El tamaño del parcho y el porcentaje de arbustos y árboles en el paisaje, no influyó en la densidad. El éxito de anidamiento resultó variable entre localidades y años, y aumento en algo con la distancia a los árboles. La tasa de parasitismo fue baja (1 de 50 nidos) y el tamaño de la camada fue similar al de otros estudios del ave.

Key words: Ammodramus leconteii, bird density, cowbird parasitism, habitat ecology, Le Conte's Sparrow, nesting biology, patch size

Breeding Le Conte's Sparrows (Ammodramus leconteiz) occupy mesic grasslands and marshes of central and southern Canada and the northernmost parts of the central United States, but also nest in other habitats such as fallow fields, hayfields, or drainage ditches (Lowther 1996; Igl and Johnson 1999). Little is known about the species because of its cryptic plumage and elusive behavior (Lowther 1996). In addition, this species exhibits large annual population

\footnotetext{
${ }^{6}$ Corresponding author. Current address: Laboratory of Ornithology, Cornell University, 159 Sapsucker Woods Rd., Ithaca, New York 14850 USA. Email: mw267@cornell.edu
}

fluctuations that may be caused by changes in soil moisture and consequent changes in vegetation structure (Igl and Johnson 1995, 1999; Igl 1999). Most published information on this species has been descriptive and lacks quantitative evaluation of factors that influence breeding densities and nesting success (Lowther 1996).

Here we provide some detail on several aspects of the breeding biology of the Le Conte's Sparrow. In particular, we report information on inter-annual and inter-regional variation in breeding densities; relationships between breeding density and nesting success, and habitat, landscape, and climatic variables; and various 


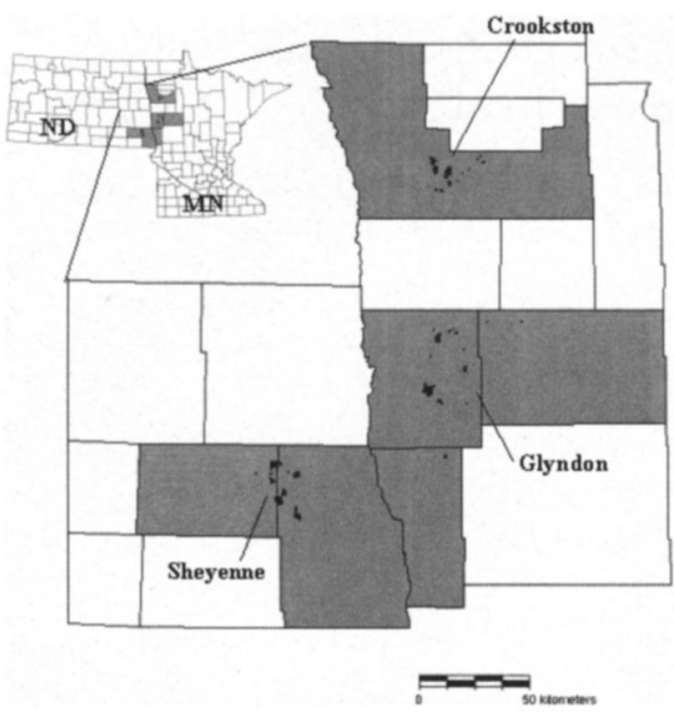

Fig. 1. Study area in the northern tallgrass prairie, 1998-2002. The study was conducted in three regions near Crookston and Glyndon, Minnesota $(\mathrm{MN})$, and in Sheyenne National Grassland, North Dakota (ND), with each region containing 11-18 study plots. Bird surveys were conducted in each study plot, whereas nest searching was conducted in a subset of the study plots.

aspects of breeding ecology including philopatry, nesting success, rates of nest parasitism by Brown-headed Cowbirds (Molothrus ater), and clutch size.

\section{METHODS AND ANALYSIS}

Study sites. We examined variation in breeding densities of Le Conte's Sparrows in 44 study plots that were established in three regions of the northern tallgrass prairie (Fig. 1): southeast of Crookston ("Crookston," 15 plots) and east of Moorhead ("Glyndon," 18 plots) in northwestern Minnesota (1998-2001), and at Sheyenne National Grassland ("Sheyenne," 11 plots) in southeastern North Dakota (19992001). A total of 160 plot-years of density data were available because not all plots were censused during each year. Nesting success was estimated on 11 plots at Crookston, 10 plots at Glyndon, and nine plots at Sheyenne, totaling 108 plot-years. Plots ranged from 1.3 to 20.6 ha in size $(\overline{\mathrm{x}}=10.6, \mathrm{SD}=5.5$ ha, $N=44$ plots), and were selected based on uniformity of vegetation structure within and among plots, with a preference for areas of little shrub or tree cover. In addition, we selected study plots based on size of the grassland patch (small, $<65$ ha; large, $>100 \mathrm{ha}$ ) and on the percentage of shrubs and trees within a $1-\mathrm{km}$ radius (treed, $>10 \%$; open, $\leq 10 \%)$. The mean size of the contiguous grassland patches in which study plots were located was 226.1 ha $(S D=341.7$; range, 2.4-1245.6 ha), and the mean percentage of shrubs and trees within the landscape was $12.4 \%$ ( $S D=10.9$; range, $1-46 \%)$. Most of our study sites were relatively level and prone to flooding after heavy rains, thus providing habitat suitable for the Le Conte's Sparrow (Lowther 1996).

We defined a grassland patch as a contiguous stretch of native or reseeded grassland that was not interrupted across $75 \%$ of its width. Interruptions could be by two- or four-lane roads (and their rights-of-way), or by wooded strips or wetlands that were at least $20 \mathrm{~m}$ wide. The sizes of patches containing a study plot ("patch size") were determined from digital orthophoto quads (DOQ's) in a geographic information system (Map and Image Processing System 6.6 and 6.7; MicroImages 2002). The DOQ's also were used to delineate and calculate areas of trees or shrubs within and to a distance of 1 $\mathrm{km}$ from the edge of each study plot ("landscape"). A $1-\mathrm{km}$ radius was large enough to include landscape data from outside even the largest grassland patches, but small enough not to overlap with the buffer zone of a neighboring study plot. Because the size of the buffer zone varied with the size of the study plot, we used the percentage of the total area that was covered by shrubs and trees within the $1-\mathrm{km}$ buffer in all analyses. We were not able to distinguish other types of landscape cover, such as agricultural fields, with the available GIS data.

Field methods. On each plot we conducted bird surveys along 100-m wide transects between 05:00 and 10:00 CST twice during each field season between early June and early July. We mapped all birds (heard or seen) and their flight paths on outlines of the study plots to minimize double-counting. For analyses we used the maximum number of males counted in each plot and standardized this number to the number of males per 100 ha ("density").

We mist-nietted Le Conte's Sparrows from late May to late July of each year on four study plots in the Crookston area, using 36- $\mathrm{mm}$ mesh 
nets (Winter et al. 2001). Most Le Conte's Sparrows were captured incidentally to our research that focused on Savannah Sparrows (Passerculus sandwichensis), Clay-colored Sparrows (Spizella pallida), and Bobolinks (Dolichonyx oryzivorus).

We quantified plot vegetation annually in early July by randomly sampling plots in such a way that the number of samples (10 to 32) varied directly with plot size. At each sampling site we estimated ground cover (bare ground, litter, grass, forb, and woody vegetation) within a $20 \times 50 \mathrm{~cm}$ Daubenmire frame (Daubenmire 1959). At each corner of the Daubenmire frame, we measured maximum vegetation height and litter depth to the nearest $0.5 \mathrm{~cm}$. We obtained visual obstruction readings in each cardinal direction to the nearest $5 \mathrm{~cm}$ by placing a Robel pole (Robel et al. 1970) in the center of the Daubenmire frame. For analyses, we used the mean values for each plot because vegetation variables measured in the same plot were not independent of each other.

Between 15 May and 31 July each year, we found nests by flushing adults from the nest vicinity or by observing adults returning to their nests (Winter et al. 2003). Nests were monitored every three to four days to determine clutch size, incidence of cowbird parasitism, and nest failure or success. A nest was considered parasitized by a Brown-headed Cowbird if it contained at least one cowbird egg or nestling, and it was considered successful if it fledged at least one host offspring. After a nest became inactive, we measured the same vegetation variables as described for plot vegetation at four sampling points within $0.5 \mathrm{~m}$ of the nest site and at one sampling point directly at the nest site (Winter 1999a). For analyses we used the mean values derived from the five sampling points at one nest. In addition, we measured the height of each nest from the ground to the bottom of the nest cup to the nearest $0.5 \mathrm{~cm}$. We visually estimated the percentage of the nest concealed by vegetation when viewed from above ("nest cover") and the distance of each nest to the nearest tree.

We obtained monthly precipitation data for 1996-2001 for each region from the National Climatic Data Center (http://lwf.ncdc.noaa.gov/ $\mathrm{oa} / \mathrm{ncdc}$.html). From the precipitation data, we calculated the Conserved Soil Moisture (CSM) index (Williams and Robertson 1965) for each region and year. Palmer Drought Severity (PDS) indices for May of each year were obtained for northwestern Minnesota and southeastern North Dakota from the National Climatic Data Center. Both CSM and PDS indices have previously been shown to be useful predictors of abundances of certain bird species (Johnson 1996; Igl and Johnson 1999).

Statistical analysis. Statistical analyses were done using SAS software (SAS Institute 1995). The Tukey-Kramer multiple comparison test and the maximum likelihood approach were used to compare mean breeding densities and the variability in mean breeding densities among study plots, years, and regions. We used a mixed-model analysis to determine which variables influenced Le Conte's Sparrow density, with study plot nested within region. Year was included as a repeated effect, because bird counts were conducted on the same study plots for several years. We used GLIMMIX, a SAS Macro for generalized Linear Mixed Models (Wolfinger and O'Connell 1993) to determine which variables influenced nesting success (as described below), with study plot nested within region, and year as random effect.

In order to reduce the number of potential models used in the analyses, we identified vegetation variables that were most promising. We randomly split the data sets into two halves and ran analyses on each half, separately for each vegetation variable (as linear or squared values); this was done 10 times, each time using different, randomly drawn data subsets. We used this procedure in lieu of procedures such as stepwise regression because such analyses yield biased standard errors and $P$-values. Variables were included in all further analyses on breeding density if they had a $P<0.1$ more frequently than in a quarter of all analyses. Because of the low number of significant effects found for nesting success, we used any variable that had a $P<$ 0.3 for the final analysis. Then we ran all possible combinations of models that included any of the selected vegetation variables and their interactive effects with region. Because of the small number of nests, we minimized the number of models on nesting success by excluding interactive terms. We used Akaike's Information Criterion for model selection adjusted for small sample sizes $\left(\mathrm{AIC}_{\mathrm{C}}\right.$; Anderson and Burnham 2002) to determine vegetation models that best described the data. 
For all further analyses of density or nesting success, we considered the model with the lowest Akaike value (either the null model or a model that had a vegetation variable added) as base model. To determine whether distance to trees (for nesting success only), patch size, percentage of shrubs and trees in the landscape, or climatic variables improved the fit of the base model, we sequentially added those variables to the base model. All variables that had a $\Delta \mathrm{AIC}_{\mathrm{C}}$ value $<4$ in the previous set of models were kept for subsequent models because we could not exclude the possibility that those variables had some influence on nesting success. After all variables had been added (yielding the "final model"), we calculated model-averaged estimates and their $90 \%$ confidence intervals (Anderson et al. 2000). However, if the final model had a $\Delta \mathrm{AIC}_{\mathrm{C}}$ value $>4$ compared to the base model, we considered the base model to be the best model and did not perform model-averaging.

We computed two estimates of daily probability of nest survival: the Mayfield estimates (Mayfield 1975; Johnson 1979) and estimates from logistic-exposure models (Shaffer 2004). Whereas the Mayfield method requires nests to be grouped into specific categories, the newly developed logistic-exposure method allows each nest to have unique values of covariates. This method is therefore more appropriate when investigating certain factors that might influence nesting success. For the logistic-exposure analysis, we split the data into two nesting intervals (before and after the penultimate nest check), such that the number of observation intervals used in the analysis is greater than the number of nests (observation intervals should not be confused with the intervals between nest checks). To estimate the probability of nest survival throughout the incubation and nestling stages, we raised either daily nest survival rate to the power of 21 (assuming $13 \mathrm{~d}$ for the incubation period and $8 \mathrm{~d}$ for the nestling period; Ehrlich et al. 1988). We also used these interval lengths to determine dates of nest initiation by back-dating nests with known hatching or fledging dates.

We calculated mean clutch size within 10 -d intervals to determine whether clutch size changed during the breeding season, using only nests found during incubation, to decrease the likelihood that clutch size had been reduced by partial depredation. Only those time periods were included that provided clutch-size information for more than one nest. Clutch size and nest and plot vegetation variables are presented as means $\pm \mathrm{SD}$.

\section{RESULTS AND DISCUSSION}

Density and return rates. Mean densities of Le Conte's Sparrows on our study areas (42.5 males $\pm 3.7 / 100 \mathrm{ha}$ ) were similar to or higher than densities reported in other studies in the northern Great Plains. Densities were comparable to those recorded in Conservation Reserve Program fields in Eddy County, North Dakota, during the peaks of irruption (Igl and Johnson 1995, 1999). Densities were much higher than those described by other studies in North $\mathrm{Da}$ kota (Renken and Dinsmore 1987; Madden 1996), which reported fewer than 5 males/ 100 ha. Average densities of other species in our study were 91.1 males/100 ha for Savannah Sparrows, 48.6 males/100 ha for Bobolinks, and 20.4 males/100 ha for Grasshopper Sparrows.

Density of Le Conte's Sparrows varied among regions and years (Table 1). Each year, density of Le Conte's Sparrows was highest in Crookston and lowest at Sheyenne, despite the species' dramatic range expansion in recent years (Igl and Johnson 1995, 1999; Leddy et al. 1999). The Sheyenne site, located in southeastern North Dakota, is near the southern edge of the species' typical breeding range (Lowther 1996; Igl and Johnson 1999), whereas the Crookston area is closer to the core. Within each region, mean density was much lower in 2001 than in the other years of the study (Table 1).

In spite of the regional and annual differences in densities of Le Conte's Sparrows, the species' densities were more variable among study plots within a region $(26 \%$ of all variation in density was explained by variation among study plots) than among regions (13\%) or among years within a region $(10 \%)$. The error term (as derived by maximum likelihood) accounted for $51 \%$ of all variation, indicating that much of the variation in density was the result of yearto-year variation within individual study plots. This variation was almost twice as high as for the Clay-colored and Savannah sparrows (Winter et al., in press). 
Table 1. Average density of Le Conte's Sparrows (males per $100 \mathrm{ha}$ ) in study plots in northwestern Minnesota (Crookston and Glyndon) and southeastern North Dakota (Sheyenne), USA. Differences in density among years within region and differences among regions significant at $\alpha=0.05$, as derived from the TukeyKramer test, are indicated by different superscripts $(N=$ number of study plots surveyed per year).

\begin{tabular}{|c|c|c|c|c|c|c|c|c|c|}
\hline \multirow[b]{2}{*}{ Year } & \multicolumn{3}{|c|}{ Crookston } & \multicolumn{3}{|c|}{ Glyndon } & \multicolumn{3}{|c|}{ Sheyenne } \\
\hline & $\overline{\mathbf{x}}$ & $\mathrm{SD}$ & $N$ & $\overline{\mathbf{x}}$ & SD & $N$ & $\overline{\mathbf{x}}$ & SD & $N$ \\
\hline 1998 & $72.7^{a}$ & 67.5 & 15 & $53.9^{a}$ & 53.2 & 18 & & & 0 \\
\hline 1999 & $62.2^{\mathrm{a}}$ & 36.3 & 15 & $44.0^{\mathrm{a}}$ & 34.6 & 18 & $18.2^{\mathrm{a}}$ & 27.2 & 11 \\
\hline 2000 & $77.0^{\mathrm{a}}$ & 57.4 & 15 & $40.8^{a}$ & 42.3 & 18 & $18.7^{a}$ & 20.2 & 11 \\
\hline 2001 & $41.0^{b}$ & 33.7 & 14 & $9.3^{b}$ & 17.4 & 14 & $1.7^{b}$ & 2.9 & 11 \\
\hline Total & $63.6^{a}$ & 51.6 & 59 & $38.6^{b}$ & 42.3 & 68 & $12.8^{c}$ & 20.6 & 33 \\
\hline
\end{tabular}

Large annual fluctuations in Le Conte's Sparrow density have also been described by Igl and Johnson (1995, 1999). Erratic population fluctuations are typical for most grassland passerines because they are highly dependent on specific vegetation features that vary dramatically in response to local moisture conditions (Igl and Johnson 1999). This is especially true for Le Conte's Sparrows, which require relatively mesic habitats (Dechant et al. 2003). High variability in population sizes reflects the species' ability to respond quickly to changing habitat quality and is essential for birds inhabiting highly variable environments (Wiens 1973). A species that is not flexible in its choice of breeding location is much more prone to experience the negative effects of habitat deterioration, as is the case for the sedentary Cape Sable Seaside Sparrow (A. maritimus mirabilis, Jenkins et al. 2003).

The large annual variation in density within our study plots is consistent with the low return rates that we documented in our study. Of the 93 birds that were banded, only one was detected on our study area in subsequent years. A female returned to the same site, a small (15ha) prairie surrounded by trees, a year after she had been banded. Le Conte's Sparrows have been reported to exhibit a "colonial" tendency when breeding (Lowther 1996), and breeding densities on our study plots at which Le Conte's Sparrows were banded were relatively high (58 to 130 males $/ 100$ ha). Therefore, the likelihood of recapturing or resightıng a banded bird in the years following banding should have been relatively high, if it returned. However, the Le Conte's Sparrow was not a focal species, and therefore effort and capture rates of this species across years were unequal, reducing our confi- dence that the return rates were as low as they appeared. In the one other study that documented return rates in Le Conte's Sparrows (Murray 1969), one of seven males and none of six female birds were resighted.

Low return rates also have been documented for other Ammodramus species, such as the Baird's Sparrow (A. bairdii; Green et al. 2002), the Henslow's Sparrow (A. henslowii; Skipper 1998; Herkert et al. 2002), and the Grasshopper Sparrow (A. savannarum; Vickery 1996; Skipper 1998). Low return rates are assumed to be typical of grassland sparrows in the northern Great Plains of North America because of the area's highly variable climatic conditions (Igl and Johnson 1999). In contrast, high return rates are found among Ammodramus species in eastern North America, such as the Grasshopper Sparrow (Vickery 1996), the Saltmarsh Sharp-tailed Sparrow (A. caudacutus, Greenlaw and Rising 1994; DiQuinzio et al. 2001), and the sedentary Florida Grasshopper Sparrow $(A$. savannarum floridanus, Delany et al. 1995).

It seems likely that annual variation in climatic conditions played some role in the annual variation in Le Conte's Sparrow density. Igl and Johnson (1999) found a strong relationship between density in this species and climatic factors. However, we found no effect of either the PDS index or the CSM index on breeding density (Tables 2,3 ), possibly because climatic variability during our study was too low to detect an effect.

rew of the vegetation variables that we measured affected Le Conte's Sparrow density. Two models that described Le Conte's Sparrow density had a $\Delta \mathrm{AIC}_{\mathrm{C}}$ value $<4$. The first model included year, the squared value of bare ground, and the interactive effect of region and vegeta- 
Table 2. The final model for Le Conte's Sparrow density was determined by sequentially adding variables to the best vegetation model, which included year, bare ground, and region $\times$ vegetation height. Data were collected in study plots in three regions of the northern tallgrass prairie, USA, 1998-2001 $(N=160$ plotyears).

\begin{tabular}{lcc}
\hline \multicolumn{1}{c}{ Model variables $^{\mathrm{a}}$} & $\Delta \mathrm{AIC}_{\mathrm{C}}$ & Akaike weight \\
\hline Patch size added & & \\
$\quad$ Vegetation & 0.00 & 0.55 \\
Vegetation, patch size & 0.65 & 0.40 \\
Vegetation, patch size $\times$ region & 5.08 & 0.04 \\
Landscape added & & \\
Vegetation, patch size & 0.00 & 0.59 \\
Vegetation, patch size, landscape & 1.03 & 0.35 \\
Vegetation, patch size, landscape $\times$ region & 4.50 & 0.06 \\
Climate added & & \\
Vegetation, patch size, landscape & 0.00 & 0.55 \\
Vegetation, patch size, landscape, CSMc & 1.67 & 0.24 \\
Vegetation, patch size, landscape, PDS & \\
\hline
\end{tabular}

${ }^{a}$ At each step, all variables were retained in the model that had a $\Delta \mathrm{AIC}_{\mathrm{C}}$ value $<4$. All parameters were estimable, and all models included two random effects (year, and plot nested within region). The number of estimable parameters is therefore the number of variables in the model plus 2 .

${ }^{b}$ All models that had a $\Delta \mathrm{AIC}_{\mathrm{C}}$ value $<4$ after adding climate variables were used for model-averaging (Table 3).

c Conserved Soil Moisture index.

d Palmer Drought Severity index.

tion height $\left(\Delta \mathrm{AIC}_{\mathrm{C}}=0\right.$; Akaike weight $=0.76$, $N=160$ plot-years). Relative to the models considered, this model had three times greater support by the data than the second-best model (which also included the squared value of grass cover; $\Delta \mathrm{AIC}_{\mathrm{C}}=2.28$; Akaike weight $\left.=0.24\right)$.
The first model therefore was used as a base model for all subsequent analyses (Table 2).

Although the models that included patch size or the percentage of shrubs and trees in the landscape had slightly higher Akaike values than the null model, there was strong support

Table 3. Model-averaged results with $90 \%$ lower and upper confidence limits (LC and UC) on the effect of vegetation variables, patch size, the percentage of shrubs and trees within $1 \mathrm{~km}$ surrounding the study plots ("Landscape"), and climate (Conserved Soil Moisture index [CSM], and Palmer Drought Severity index [PDS]) on Le Conte's Sparrow density in the northern tallgrass prairie, USA, 1998-2001 ( $N=160$ plotyears).

\begin{tabular}{lccrrr}
\hline \multicolumn{1}{c}{ Parameter } & Year & Region & Estimate & \multicolumn{1}{c}{ LC } & \multicolumn{1}{c}{ UC } \\
\hline Intercept & & 1.95 & -47.61 & 51.51 \\
(Bare ground cover) $^{2}$ & & & -0.05 & -0.07 & -0.03 \\
Vegetation height $\times$ region & & Crookston & 1.29 & 0.71 & 1.86 \\
& & Glyndon & 0.49 & -0.54 & 1.52 \\
Patch size & & Sheyenne & 0.16 & -0.55 & 0.88 \\
Landscape & & 0.01 & -0.01 & 0.03 \\
PDS & & -0.44 & -1.06 & 0.18 \\
CSM & & 1.14 & -3.35 & 5.63 \\
Year & & -0.04 & -0.19 & 0.11 \\
& 1998 & & 26.53 & 7.40 & 45.66 \\
& 1999 & & 24.92 & 8.86 & 40.99 \\
& 2000 & & 22.45 & 9.97 & 34.94 \\
\hline
\end{tabular}


from the data ( $40 \%$ and $35 \%$, respectively) for the model that included both vegetation variables and patch size or the percentage of shrubs and trees (Table 2). $\Delta \mathrm{AIC}_{\mathrm{C}}$ values for the vegetation models that included patch size, percentage shrubs and trees in the landscape, and climatic variables were similar to that of the best vegetation model that did not include those additional factors (Table 2). We therefore averaged the estimates and standard errors across the best three models (Burnham and Anderson 2002; Table 3).

Model-averaging showed only three variables that had confidence intervals that did not include zero (Table 3), thus indicating a close relationship between those variables and density in Le Conte's Sparrows. Le Conte's Sparrow density decreased with either high or low amounts of bare ground, increased with higher vegetation at Crookston, and varied among years. As a typical Ammodramus species, Le Conte's Sparrows forage mainly on or near the ground (Lowther 1996). Moderate ground cover is probably beneficial for ground-foraging species because it provides a balance between foraging efficiency and cover from predators. A similar relationship has previously been shown for Baird's Sparrows (Winter 1999b).

These results indicate that predictions of Le Conte's Sparrow density based on patch size and percentage of shrubs and trees in the landscape will be useless if the models do not include information about local vegetation structure. Similarly, Johnson and Igl (2001) did not find an overall effect of patch size on Le Conte's Sparrow density in the northern Great Plains. This pattern differs from that in most other Ammodramus species, which have been described as area sensitive (Vickery 1996; Winter and Faaborg 1999; Benoit and Askins 2002; Green et al. 2002; Herkert et al. 2002; Davis 2003a). In our study, mean patch size may have been too large, and the percentage of shrubs and trees in the landscape too low, to demonstrate influences on distributions in Le Conte's Sparrows.

Nesting biology. We found 50 Le Conte's Sparrow nests during five years. Few Le Conte's Sparrow nests have been found, probably because of the species' highly secretive behavior and well-concealed nests (Lowther 1996). Like other Ammodramus species, this species walks rather than flies to its nest and usually flushes several meters away from the nest (Winter et al. 2003). In our study, we found 42 nests in the Crookston region, eight nests in the Glyndon region, and none at Sheyenne National Grassland. These numbers reflect the variation in density of Le Conte's Sparrows across the three regions (Lowther 1996; this study).

In our study area, the species' breeding season appeared to be relatively short: the nests we found were initiated between 17 May and 8 July. Between 24 May and 3 June, 53\% of all nests were initiated, with a median date of 29 May. Because we concentrated nest-searching efforts on other species, we may have missed potential re-nesting or double-brooding events. These seem likely given that the length of the Le Conte's Sparrow breeding season can extend to the end of August or even early September (Murray 1969; Faanes 1981), and that some Ammodramus species have been reported to have two broods per season (Greenlaw and Rising 1994; Vickery 1996; Winter 1999a; Green et al. 2002; Herkert et al. 2002).

Nests contained on average 4.51 $( \pm 0.56, N$ $=33$ ) eggs, which is similar to the clutch sizes reported from other nesting studies of Le Conte's Sparrows (Lowther 1996). The clutch size also is similar to other Ammodramus species inhabiting tallgrass or mixed-grass prairie in the Midwest (Vickery 1996; Davis and Sealy 1998; Green et al. 2002; Herkert et al. 2002; Davis 2003b). As shown for other species (Dhondt et al. 2002; Davis 2003b), clutch size decreased later in the breeding season (rate: $-0.18 \pm$ 0.03 eggs per $10 \mathrm{~d}, R^{2}=0.92, F=34.8, P=$ $0.010, N=510-\mathrm{d}$ intervals). An average of $3.32( \pm 1.61, N=34)$ eggs hatched and 2.24 $( \pm 2.01, N=45)$ young fledged. From successful nests, 3.88 young $( \pm 0.71, N=26)$ fledged. The number of young fledged from all nests combined was higher than that reported for the closely related Henslow's Sparrow (Winter 1999a) and Baird's Sparrow (Davis 2003b).

Of 45 nests with known fates, 26 nests were successful, 18 nests were depredated, and one nest was abandoned for unknown reasons. The estimated Mayfield daily nest survival rate based on 432 exposure days and 19 unsuccessful nests was $0.956 \pm 0.009(N=45)$. This estimate was almost identical to that of the logistic-exposure model $(0.957,95 \%$ CL 0.905-0.981). Based on these nesting success estimates, nest survival during the incubation and nestling pe- 
Table 4. Vegetation characteristics of Le Conte's Sparrow nests and of plots in which Le Conte's Sparrows were found in the northern tallgrass prairie, USA, 1998-2002.

\begin{tabular}{|c|c|c|c|c|c|c|}
\hline & \multicolumn{2}{|c|}{ Nest $(N=43)^{\mathrm{a}}$} & \multicolumn{2}{|c|}{ Plot $(N=109)^{\mathrm{b}}$} & \multirow[b]{2}{*}{$t$} & \multirow[b]{2}{*}{$P$} \\
\hline & $\overline{\mathrm{x}}$ & $\mathrm{SD}$ & $\overline{\mathbf{x}}$ & $\mathrm{SD}$ & & \\
\hline Bare ground cover $(\%)$ & 0.5 & 1.5 & 3.3 & 7.8 & -3.70 & $<0.001$ \\
\hline Grass cover $(\%)$ & 37.6 & 15.8 & 35.0 & 9.9 & -0.07 & 0.948 \\
\hline Forb cover $(\%)$ & 15.6 & 11.6 & 20.7 & 9.3 & -1.30 & 0.202 \\
\hline Litter cover $(\%)$ & 45.3 & 17.3 & 38.7 & 13.3 & 2.23 & 0.033 \\
\hline Woody cover (\%) & 0.2 & 0.7 & 1.4 & 1.7 & -6.71 & $<0.001$ \\
\hline Litter depth $(\mathrm{cm})$ & 6.1 & 2.5 & 5.2 & 2.8 & 1.33 & 0.185 \\
\hline Vegetation height $(\mathrm{cm})$ & 37.3 & 9.6 & 46.8 & 9.1 & -3.16 & 0.002 \\
\hline Visual obstruction (dm) & 1.9 & 0.9 & 2.6 & 0.8 & -3.24 & 0.001 \\
\hline
\end{tabular}

a Number of nests for which vegetation was characterized.

b Number of plot-years. For analysis we used only those study plots in which nests were found $(N=27$ plots).

riods was $38.9 \%$ and $39.7 \%$, respectively. This rate of nesting success was higher than the rates for three other grassland species that we have investigated so far (Savannah Sparrow, Claycolored Sparrow, and Bobolink; M. Winter et al., unpubl. data). Potential factors influencing high rates of nesting success (and low rates of brood parasitism, as described below) are wellhidden nests, secretive behavior, distance of nests from potential perch sites for avian nest predators and cowbirds, and the location of our study areas outside the area of highest cowbird densities (based on Breeding Bird Survey data; Price et al. 1995).

Only one of 50 Le Conte's Sparrow nests was parasitized by a Brown-headed Cowbird. This nest contained two host young and two cowbird eggs; all young were depredated during the nestling stage. This cowbird parasitism rate was lower than that of any focal grassland passerine that we studied (M. Winter et al., unpubl. data). Although Lowther (1996) noted that cowbird parasitism occurred relatively frequently in Le Conte's Sparrows, that view was based largely on studies with sample sizes of fewer than six nests. Among other Ammodramus species, low parasitism rates have been reported for Henslow's Sparrows (Winter 1999a; Herkert et al. 2002; Shaffer et al. 2003), but rates for Baird's Sparrows and Grasshopper Sparrows are moderate to high (Shaffer et al. 2003).

Nests typically were placed on or close to the ground $(\overline{\mathrm{x}}=2.6 \mathrm{~cm}$ high, $\mathrm{SD}=3.6, N=46$ nests) within dead plant material (96\% of 44 nests were built in litter), and were largely covered by surrounding vegetation $(\bar{x}=86.9 \%$,
$\mathrm{SD}=21.5, N=46)$. Well-hidden nests are typical for most Ammodramus species (Lowther 1996; Vickery 1996; Winter 1999a; Green et al. 2002; Herkert et al. 2002). Although nests were on average placed far from trees $(\overline{\mathrm{x}}=$ $123.1 \mathrm{~m}, N=46$ ), variation in nest placement among nests was considerable $(\mathrm{SD}=124.6)$. We therefore have no clear evidence that Le Conte's Sparrows avoid trees for nest placement, as has been documented for several grassland passerines (O'Leary and Nyberg 2000; Johnson et al. 2003). Compared to the vegetation at random sites in the study plots in which Le Conte's Sparrows were found, nest sites were in areas with less bare ground and woody vegetation and with higher litter cover (Table 4). In addition, Le Conte's Sparrows chose nest sites that were surrounded by shorter and less dense vegetation.

None of the nest vegetation variables could explain variation in nesting success because none of the vegetation models had an Akaike value lower than the null model. Vegetation may be a poor indicator of the likelihood of a nest being successful (Winter 1999a; Hughes et al. 2000; Winter et al., in press). This apparent lack of influence of vegetation structure on nesting success might be due to the diverse species composition and distribution of nest predators in grassland systems (Pietz and Granfors 2000; M. Winter et al., unpubl. data). Nesting success of Le Conte's Sparrows was most influenced by the distance to trees (Table 5); nesting success increased slightly with increasing distance to trees (slope $=0.02$ per $100 \mathrm{~m}, \mathrm{SD}=$ $0.02, N=39$ ). Such a positive effect was ex- 
Table 5. The final model for Le Conte's Sparrow nesting success was determined by sequentially adding variables to the null model, using Shaffer's logistic-exposure model (Shaffer 2004). Data were collected in study plots situated in two regions of the northern tallgrass prairie, USA, 1998-2002 ( $N=39$ nests). See Table 2 for analysis procedure and definitions of abbreviations.

\begin{tabular}{lcc}
\hline \multicolumn{1}{c}{ Model variables } & $\Delta \mathrm{AIC}_{\mathrm{C}}$ & Akaike weight \\
\hline Distance to tree added & & \\
$\quad$ Distance & 0.00 & 0.96 \\
$\quad$ Null & 6.36 & 0.04 \\
Patch size added & & \\
$\quad$ Distance & 0.00 & 0.84 \\
$\quad$ Distance, patch size & 3.37 & 0.16 \\
Landscape added & & \\
$\quad$ Distance, patch size & 0.00 & 0.79 \\
Distance, patch size, landscape & 2.63 & 0.21 \\
Climate added & & \\
$\quad$ Distance, patch size, landscape & 0.00 & 0.64 \\
Distance, patch size, landscape, PDS & 2.05 & 0.23 \\
Distance, patch size, landscape, CSM & 3.25 & 0.13 \\
\hline
\end{tabular}

pected because nest predation and cowbird parasitism are frequently higher close to woody edges (Johnson and Temple 1990; Winter et al. 2000).

Neither patch size, percentage of shrubs and trees in the landscape, nor climate improved the fit of the distance model on nesting success ( $\mathrm{Ta}$ ble 5). We expected lower nesting success in small grassland patches and in areas of relatively high amounts of shrubs and trees because of the larger amount of woody edge habitat in such areas. In forested systems, small patch sizes and low forest cover in the surroundings can reduce nesting success of forest-breeding birds (Robinson et al. 1995; Donovan et al. 1997). In grassland systems, few studies have demonstrated a negative effect of patch size on nesting success (Winter and Faaborg 1999; Balent and Norment 2003; Davis 2003a), and effects of landscape variables on nesting success have not yet been clearly demonstrated. Patch sizes in our study may have been too large, and the percentage of shrubs and trees in the landscape too few, to influence nesting success of Le Conte's Sparrows.

\section{ACKNOWLEDGMENTS}

We appreciate the efforts of T. L. Shaffer, who developed the methodology that we used for our analyses of nesting success. We thank L. D. Igl for thoughtful comments on earlier drafts of the manuscript, S. K. Davis and an anonymous reviewer for helpful comments on the manuscript, and W. M. Hochachka for statistical and programming advice. This research would not have been possible without the enormous effort of all the field assistants and volunteers who participated in the project. This study was funded by the U.S. Geological Survey and the U.S. Fish and Wildlife Service Regions 3 and 6.

\section{LITERATURE CITED}

Anderson, D. R., And K. P. Burnham. 2002. Avoiding pitfalls when using information-theoretic methods. Journal of Wildlife Management 66: 912-918.

$\longrightarrow$, , AND W. L. Thompson. 2000. Null hypothesis testing: problems, prevalence, and an alternative. Journal of Wildlife Management 64: 912-923.

Balent, K. L., ANd C. J. Norment. 2003. Demographic characteristics of a Grasshopper Sparrow population in a highly fragmented landscape of western New York State. Journal of Field Ornithology 74: 341-348.

Benoit, L. K., AND R. A. Askins. 2002. Relationship between habitat area and the distribution of tidal marsh birds. Wilson Bulletin 114: 314-323.

Burnham, K. P., And D. R. Anderson. 2002. Model selection and inference: a practical information-theoretic approach, 2nd ed. Springer, New York, NY.

DaubenMire, R. 1959. A canopy-coverage method of vegetational analysis. Northwest Science 33: 43-64.

DAVIS, S. K. 2003a. Habitat selection and demography of mixed-grass prairie songbirds in a fragmented landscape. Ph.D. dissertation. University of Regina, SK.

. 2003b. Nesting ecology of mixed-grass prairie songbirds in southern Saskatchewan. Wilson Bulletin 115: 119-130.

—, AND S. G. SEALY. 1998. Nesting biology of the 
Baird's Sparrow in southwestern Manitoba. Wilson Bulletin 110: 262-270.

Dechant, J. A., M. L. Sondreal, D. H. Johnson, L. D. Igl, C. M. Goldade, A. L. Zimmerman, AND B. R. Euliss. 2003. Effects of management practices on grassland birds: Le Conte's Sparrow. Northern Prairie Wildlife Research Center, Jamestown, ND. http://www.npwrc.usgs.gov/resource/literatr/ grasbird/lcsp/lcsp.htm (12 December 2003).

Delany, M. F., C. T. Moore, and D. R. Progulske. 1995. Territory size and movements of Florida Grasshopper Sparrows. Journal of Field Ornithology 66: 305-309.

Dhondt, A. A., T. L. Kast, and P. E. Allen. 2002. Geographical differences in seasonal clutch size variation in multi-brooded bird species. Ibis 144: 646651.

DiQuinzio, D. A., P. W. C. Paton, and W. R. EddLEMAN. 2001. Site fidelity, philopatry, and survival of promiscuous Saltmarsh Sharp-tailed Sparrows in Rhode Island Auk 118: 888-899.

Donovan, T. M., P. W. Jones, E. M. Annand, and F. R. THOMPSON. 1997. Variation in local-scale edge effects: mechanisms and landscape context. Ecology 78: 2064-2075.

Ehrlich, P. R., D. S. Dobkin, And D. Wheye. 1988. The birder's handbook. Simon and Schuster, New York, NY.

FAANES, C. A. 1981. Birds of the St. Croix River Valley: Minnesota and Wisconsin. North American Fauna 73, U.S. Fish and Wildlife Service, Washington, D.C.

Green, M. T., P. E. Lowther, S. L. Jones, S. K. Davis, AND B. C. DAle. 2002. Baird's Sparrow (Ammodramus bairdit). In: The birds of North America (A. Poole, and F. Gill, eds.), no. 638. The Birds of North America, Inc., Philadelphia, PA.

Greenlaw, J. S., and J. D. Rising. 1994. Sharp-tailed Sparrow (Ammodramus caudacutus). In: The birds of North America (A. Poole, and F. Gill, eds.), no. 112. Academy of Natural Sciences, Philadelphia, PA, and American Ornithologists' Union, Washington, D.C.

Herkert, J. R., P. D. Vickery, and D. E. Kroodsma. 2002. Henslow's Sparrow (Ammodramus henslowii). In: The birds of North America (A. Poole, and F. Gill, eds.), no. 672. The Birds of North America, Inc., Philadelphia, PA.

Hughes, J. P., R. J. Robel, and K. E. Kemp. 2000. Factors influencing Mourning Dove nesting success in CRP fields. Journal of Wildlife Management 64: 1004-1008.

IGL, L. D. 1999. Le Conte's Sparrow: ephemeral jewel of the northern Great Plains. North Dakota Outdoors 61: 10-13.

- ANI) D. H. Johnson. 1995. Dramatic increase of Le Conte's Sparrow in Conservation Reserve Program fields in the northern Great Plains. Prairie Naturalist 27: 89-94.

— AND $\longrightarrow$ 1999. Le Conte's Sparrows breeding in Conservation Reserve Program fields: precipitation and patterns of population change. Studies in Avian Biology 19: 178-186.

Jenkins, C. N., R. D. Powell, O. L. Bass, and S. L.
Pimm. 2003. Why sparrow distributions do not match model predictions. Animal Conservation 6: $39-46$.

JoHnson, D. H. 1979. Estimating nest success: the Mayfield method and an alternative. Auk 96: 651661 .

-1996. Waterfowl communities in the northern Plains. In: Long term studies of vertebrate communities (M. L. Cody, and J. A. Smallwood, eds.), pp. 391-418. Academic Press, San Diego, CA.

- AND L. D. IGL. 2001. Area requirements of grassland birds: a regional perspective. Auk 118: 24-34.

- $\longrightarrow$ and J. A. Dechant Shaffer. 2003.

Effects of management practices on grassland birds. Northern Prairie Wildlife Research Center, U.S. Geological Survey, Jamestown, ND. http://www. npwrc.usgs.gov/resource/literatr/grasbird/grasbird. htm (4 September 2003).

Johnson, R. G., and S. A. Temple. 1990. Nest predation and brood parasitism of tallgrass prairie birds. Journal of Wildlife Management 54: 106 111.

Leddy, K. L., K. F. Higgins, and D. E. Naugle. 1999. Effects of wind turbines on upland nesting birds in Conservation Reserve Program grasslands. Wilson Bulletin 111: 100-104.

LowTHER, P. E. 1996. Le Conte's Sparrow (Ammodramus lecontei $i$ ). In: The birds of North America (A. Poole, and F. Gill, eds.), no. 224. Academy of Natural Sciences, Philadelphia, PA, and American Ornithologists' Union, Washington, D.C.

Madden, E. M. 1996. Passerine communities and birdhabitat relationships on prescribe-burned, mixedgrass prairie in North Dakota. M.S. thesis. Montana State University, Bozeman, MT.

Mayfield, H. F. 1975. Suggestions for calculating nest success. Wilson Bulletin 87: 456-466.

MicroImages, INC. 2002. Lincoln, NE. http://www. microimages.com

Murray, B. G. 1969. A comparative study of the Le Conte's and Sharp-tailed sparrows. Auk 86: 199231.

O'Leary, C. H., and D. W. Nyberg. 2000. Treelines between fields reduce the density of grassland birds. Natural Areas Journal 20: 243-249.

Pietz, P. J., and D. A. Granfors. 2000. Identifying predators and fates of grassland passerine nests using miniature video cameras. Journal of Wildlife Management 64: 71-87.

Price, J., S. Droege, And A. Price. 1995. The summer atlas of North American birds. Academic Press, London, UK.

Renken, R. B., and J. J. Dinsmore. 1987. Nongame bird communities on managed grasslands in North Dakota. Canadian Field-Naturalist 101: 551-557.

Robel, R. J., J. N. Briggs, A. D. Dayton, and L. C. Hulbert. 1970. Relationship between visual obstruction measurements and weight of grassland vegetation. Journal of Range Management 23: 295297.

Robinson, S. K., F. R. ThOMPSON, III, T. M. DONOVAN, D. R. WhiteHEAd, AND J. FAABORG. 1995. 
Regional forest fragmentation and the nesting success of migratory birds. Science 267: 1987-1990.

SAS INSTITUTE, INC. 1995. SAS/STAT user's guide, release 6.03. SAS Institute, Inc., Cary, NC.

Shaffer, J. A., C. M. Goldade, M. F. Dinkins, D. H. Johnson, L. D. IGL, AND B. R. Euliss. 2003. Brown-headed Cowbirds in grasslands: their habitats, hosts, and response to management. Prairie Naturalist 35: 146-186.

SHAFFER, T. L. 2004. A unified approach to analyzing nest success. Auk 121: 526-540.

SKIPPER, C. S. 1998. Henslow's Sparrows return to previous nest site in western Maryland. North American Bird Bander 23: 36-41.

VICKERY, P. D. 1996. Grasshopper Sparrow (Ammodramus savannarum). In: The birds of North America (A. Poole, and F. Gill, eds.), no. 239. Academy of Natural Sciences Philadelphia, PA, and American Ornithologists' Union, Washington, D.C.

WIENS, J. A. 1973. Patterns and processes in grassland bird communities. Ecological Monographs 43: 237-270.

Williams, G. D., AND G. W. Robertson. 1965. Estimating most probable prairie wheat production from precipitation data. Canadian Journal of Plant Science 45: 34-47.

WINTER, M. 1999a. Nesting behavior and nest success of Henslow's Sparrows and Dickcissels in south- western Missouri prairie fragments. Wilson Bulletin 111: 515-527.

. 1999b. Impacts of fire on Baird's Sparrow habitat in northern mixed-grass prairie. Studies in Avian Biology 19: 171-177.

AND J. FAABORG. 1999. Patterns of area-sensitivity in grassland-nesting birds. Conservation $\mathrm{Bi}$ ology 13: 1324-1434.

, S. E. Hawks, J. A. Shaffer, and D. H. JohNSON. 2003. Guidelines for finding nests of passerine birds in tallgrass prairie. Prairie Naturalist 35: 197211.

, D. H. Johnson, J. A. Dechant, T. M. DonOVAN, AND W. D. SVEDARSKY. 2001. Evaluation of the bird conservation area concept in the northern tallgrass prairie. Annual report: 2001. Northern Prairie Wildlife Research Center, U.S. Geological Survey, Jamestown, ND. http://www.npwrc.usgs. gov/resource/2002/bca2001/bca2001.htm (4 March 2002).

, AND J. FAABORG. 2000. Evidence for edge effects on multiple levels in tallgrass prairie. Condor 102: 256-266.

, AND J. A. SHAFFER. In press. Variability in vegetation effects on density and nesting success of grassland birds. Journal of Wildlife Management.

Wolfinger, R., AND M. O'ConNell. 1993. Generalized linear mixed models: a pseudo-likelihood approach. Journal of Statistical Computation and Simulation 48: 233-243. 